Historia Slavorum Occidentis

2019, nr 3 (22)

ISSN 2084-1213

DOI: $10.15804 /$ hso 190306

Klemens Kaps (Linz)

\title{
Gospodarka, polityka a tożsamości: Galicja i Monarchia Habsburska w długim XIX wieku na tle debaty historiograficznej o imperium, narodzie i regionie ${ }^{1}$
}

Słowa kluczowe: Galicja, Monarchia Habsburska, rozwój gospodarczy, ponadregionalny podział pracy, tożsamości narodowe, historia imperialna

Keywords: Galicia, Habsburg Monarchy, economic development, transregional division of labour, national identities, Empire history

\begin{abstract}
This article takes a fresh look on the status of Galicia within the Habsburg Monarchy between the late $18^{\text {th }}$ and the early $20^{\text {th }}$ century, presenting the obstacles and opportunities of economic growth faced by imperial policy-makers. At the same time, an analysis is presented of the impact of the imperial experience on the process of forging national identities. The emphasis has been placed on how the increasing national fragmentation in a multi-cultural region affected economic prosperity.
\end{abstract}

\section{Wprowadzenie: refleksje na temat przestrzennego podejścia w historiografii. Pomiędzy historią globalną a historią regionalną}

W ostatnich latach toczą się w historiografii debaty nad znaczeniem jednostek społeczno-przestrzennych w analizie historycznej. Wychodząc z koncepcji tzw. spatial

\footnotetext{
1 Niniejsze rozważania odnoszą się do książki K. Kaps, Ungleiche Entwicklung in Zentraleuropa. Galizien zwischen überregionaler Arbeitsteilung und imperialer Politik (1772-1914), Wien 2015. Książka jest drukowaną wersją rozprawy doktorskiej autora artykułu, obronioną na Uniwersytecie Wiedeńskim w 2011 r.
} 
turn nie można dziś już jednoznacznie stwierdzić, że jedna jednostka przestrzenna ma przewagę nad innymi, tj. np. historia regionalna nad narodową, chociaż wielu historyków zazwyczaj zachowuje dystans do narracji czysto narodowej, zwłaszcza do jej bardziej nacjonalistycznych interpretacji i to nie tylko z perspektywy nowopowstałej historii globalnej. W tym sensie perspektywa historii ponadnarodowej odzwierciedla się na obszarze historii globalnej i wchodzi w interakcje z perspektywą ponadregionalną i ponadnarodową $a^{2}$ Tak więc w odróżnieniu do wcześniejszych tendencji, w ramach tzw. spatial turn rozwija się w ostatnich latach silnie perspektywa, która w analizie historycznej nie skupia się wyłącznie na jednym poziomie, ale stara się pokazać połączenia i współzależności pomiędzy trzema kategoriami przestrzennymi: regionem, narodem i imperium. Z punktu widzenia, który uwzględnia wspólne powiązania pomiędzy tymi trzema obszarami, przedstawione zostanie kilka refleksji na temat historii Galicji od momentu jej utworzenia w wyniku pierwszego rozbioru Rzeczypospolitej Obojga Narodów do wybuchu pierwszej wojny światowej. W centrum uwagi niniejszego tekstu znajdzie się rozwój gospodarki galicyjskiej. Przedstawiona analiza ścisłe wiąże ze sobą historię społeczną, kulturową i polityczną.

Punktem wyjścia jest dobrze znany fakt, że Galicja pod koniec XVIII w. była zdecydowanie najbiedniejszym regionem Monarchii Habsburskiej i pozostała nim aż do wybuchu pierwszej wojny światowej, pomimo znacznych zmian gospodarczych i rozwoju ${ }^{3}$. Wciąż żywe wyobrażenia i stereotypy na temat Galicji, takie jak „nędza Galicji” lub „Golicja i Głodomeria” można skonfrontować z perspektywą historii gospodarczej. Szacunki i obliczenia produktu krajowego brutto pokazują bowiem, że w Monarchii Habsburskiej tylko Dalmacja i Chorwacja były w tym czasie na podobnie niskim poziomie dobrobytu 5 .

2 Zob. np.: Comparative and Transnational History. Central European Approaches and New Perspectives, red. H.-G. Hauptmann, J. Kocka, New York 2009; A. Komlosy, Globalgeschichte. Methoden und Theorien, Wien-Köln-Weimar 2011; J. Osterhammel, Die Verwandlung der Welt. Eine Geschichte des 19. Jahrhunderts, München 2011.

3 K. Broński, Problem zacofania gospodarczego Galicji. Mit i fakty, [w:] Historia gospodarcza i historia myśli ekonomicznej a teoria ekonomii, red. J. Skodlarski, Łódź 2008, s. 67-82.

4 A. Staudacher, Die sozialrevolutionäre Bewegung in Galizien 1878-1884, Wien 1986, s. 13; M. Śliwa, Nędza Galicyjska. Mit i rzeczywistość, [w:] Galicja i jej Dziedzictwo, t. I, Historia i Polityka, red. W. Bonusiak, J. Buszko, Rzeszów 1994, s. 145-155.

5 Zob. szacunki i obliczenia PKB różnych regionów monarchii habsburskiej między latami 1785-1789 a 1913 r.: P.G.M. Dickson, Finance and Government under Maria Theresia 1740-1780, t. I, Oxford 1987, s. 137; N.T. Gross, An Estimate of Industrial Product in Austria in 1841, Journal of Economic History 28 (1968), s. 80-110. D. Good, The Economic Lag of Central and Eastern Eu- 
W ujęciu historii gospodarczej kwestia przyczyn ograniczonego rozwoju Galicji w tzw. długim XIX w. wydaje się oczywista. Jednak w przeciwieństwie do innych prac historycznych, w niniejszym artykule podkreślone zostało przeplatanie się perspektyw historycznych, które można przypisać do dwóch głównych obszarów. Z jednej strony chodzi o interakcję Galicji z terenami położonymi poza jej granicami. W tym przypadku uwaga skupia się na handlu towarami, na przepływie kapitału i na migracji. Procesy wymiany są postrzegane jako część ponadregionalnego podziału pracy. Koncepcja podziału pracy wywodzi się z teorii klasyków ekonomicznych Adama Smitha i Davida Ricardo. Mówi ona, że każdy obszar, obojętnie czy jest to państwo, państwo narodowe lub region, skupia się na produkcji wyrobów, które może wytwarzać w najbardziej ekonomiczny sposób, tj. dysponuje optymalnymi warunkami do danej produkcji. To prowadzi ostatecznie do względnie równych lub przynajmniej zrównoważonych poziomów rozwoju i wysokości dochodów ${ }^{6}$. Stojąca za tymi założeniami koncepcja porównawczych korzyści Ricardo jest jednak dość problematyczna. Wychodząc od koncepcji centrum-peryferia i rozważań ekonomisty Erika Reinerta można stwierdzić, że nie każdy rodzaj działalności prowadzi do tego samego dobrobytu i rozwoju ${ }^{7}$. Różnica między obszarami rolniczymi a obszarami przemysłowymi uzasadnia raczej ostre formy przestrzennej nierówności w dystrybucji dobrobytu. Dotyczy to także innej kluczowej koncepcji, a mianowicie nierówności lub też dywergencji pomiędzy różnymi regionami ${ }^{8}$.

$\mathrm{Z}$ drugiej strony zasadniczym przedmiotem pracy jest znalezienie przyczyn powstawania dysproporcji regionalnych i ich możliwych zmian, zarówno zmniejszania się różnic, jak i dalszego ich narastania. Owa nierówność jest zanalizowana głównie w kontekście integracji Galicji w ponadregionalnym podziałem pracy. Oczywiście, wewnętrzne warunki wstępne - takie jak zasoby naturalne, struktury społeczne, in-

rope. Evidence from the Late Nineteenth-Century Habsburg Empire, Working Papers in Austrian Studies 93-7, (1993); M.-S. Schulze, Regional Income Dispersion and Market Potential in the Late Nineteenth Century Hapsburg Empire, Economic History Working Papers 106/07, London 2007.

6 A. Smith, The Wealth of Nations, Books I-III, red. A.S. Skinner, London 1999 [1776]; D. Ricardo, On the Principles of Political Economy and Taxation, London 1987 [1817].

7 T.K. Hopkins, I. Wallerstein, Grundzüge der Entwicklung des modernen Weltsystems. Entwurffür ein Forschungsvorhaben, [w:] Kapitalistische Weltökonomie. Kontroversen über ihren Ursprung und ihre Entwicklungsdynamik, red. D. Senghaas, Frankfurt 1979, s. 151-200; E. Reinert, How rich countries got rich and why poor countries stay poor, New York 2008.

8 K. O'Rourke, J. Williamson, Globalization and History: The Evolution of a Nineteenth-Century Atlantic Economy, Cambridge/MA 1999, s. 6 n. 
frastruktura i polityka gospodarcza - także są uwzględniane w ich interakcji z ponadregionalną integracją rynkową.

W tym miejscu należy przywołać kilka refleksji na temat koncepcji samego regionu. W momencie ukierunkowania się nauk historycznych na przestrzeni jako jednostce badawczej, przedmiotem badań stały się także małe obszary. Niejednokrotnie w połączeniu z innymi nurtami historiograficznymi, takimi jak historia codzienności lub mikrohistoria, znaczenia nabrało studiowanie transformacji społecznej na obszarze wiejskim lub ogólnie w przestrzeniach oddalonych od władzy ${ }^{9}$. W takim ujęciu chodzi również o częściową relatywizację narracji o centralizacji państwa. $\mathrm{W}$ przeciwieństwie do teorii modernizacji, centralizacja nie była uwzględniona jako proces sterowany od góry ${ }^{10}$.

Obszar może być oczywiście różnie zdefiniowany - przez naturalne granice geograficzne lub polityczno-administracyjne, przez wspólną tożsamość i wspólne relacje lub powiązania w biznesie czy w kulturze. Te ostatnie definicje jasno pokazują, że regiony mogły wykraczać poza granice państwowe ${ }^{11}$. W przypadku Galicji dominowała ściśle związana z imperium polityczno-administracyjna definicja regionu silnie związana z czynnikami kulturowymi i ekonomicznymi.

Do tego aspektu ponadregionalnej współzależności dodaje się drugi, bardziej polityczny - imperium lub, bardziej precyzyjnie, politykę imperialną. Jest to z jednej strony stosunkowo oczywisty punkt widzenia. Monarchię habsburską można opisać, co najmniej od XVIII w., jako imperium, które dominowało na odległych i zróżnicowanych kulturowo obszarach Europy Środkowej ${ }^{12}$. Zaklasyfikowanie obszaru

9 Regions and Industries. A perspective on the industrial revolution in Britain, red. P. Hudson, Cambridge 1989; A. Komlosy, Grenze und ungleiche regionale Entwicklung. Binnenmarkt und Migration in der Habsburgermonarchie, Wien 2003; H. Madurowicz-Urbańska, Forschungen über die landwirtschaftlichen Regionen Polens im Zeitraum vom 16. bis zum 19. Jahrhundert, [w:] Studia Historiae Oeconomicae 7 (1972), s. 91-98; Grenzregionen der Habsburgermonarchie im 18. und 19. Jahrhundert. Ihre Bedeutung und Funktion aus der Perspektive Wiens, red. H.-C. Maner, Münster 2005; A. Podraza, Europa - Galicja - Regiony. Pisma historyczne, Kraków 2006. 10 Empowering Interactions. Political Cultures and the Emergence of the State in Europe 1300-1900, red. W. Blockmans, A. Holenstein, J. Mathieu, Farnham-Burlington 2009.

11 A. Podraza, Galicja, s. 45, 52-55.

12 A. Strohmeyer, Die Habsburgermonarchie in der Frühen Neuzeit - ein Imperium? Ein Problemaufriss, [w:] Imperien und Reiche in der Weltgeschichte. Epochenübergreifende und globalhistorische Vergleiche. Teil 2: Neuzeitliche Imperien, Imperien in Theorie, Geist, Wissenschaft, Recht und Architektur, Wahrnehmung und Vermittlung, red. M. Gehler, R. Rollinger, Wiesbaden 2014, s. 1027-1055. 
rządzonego przez Habsburgów jako imperium nabiera nowego znaczenia w świetle historiograficznych debat ostatnich lat. W nowo powstałej koncepcji historii globalnej badania nad imperium są intensyfikowane od kilku lat. Można wspomnieć ujęcia Jürgena Osterhammela ${ }^{13}$, Jane Burbank lub Frederica Coopera ${ }^{14}$, jak również prace Michaela Gehlera i Rolanda Rollingera, ${ }^{15}$ Herfrieda Münklera ${ }^{16}$, a ostatnio Hansa-Heinricha Nolte ${ }^{17}$. W szczególności Nolte wniósł nowy wymiar do dyskusji przez swoją propozycję klasyfikacji różnych rodzajów imperiów na przestrzeni wieków i tysiącleci, jak też przez opracowanie 12 kryteriów definicji cesarskich form państwowych. Te rozciągają się od roli dynastii i szlachty do silnej centralnej biurokracji i pobierania podatków, ale też uwzględniają przypadek niekoniecznie potężnego państwa, które jednak efektywnie zarządza różnicami kulturowymi i różnicami pomiędzy centrum i peryferią, ponieważ jest otwarte na kompromisy regionalne. Przemoc, przymus lub ucisk pojawiają się w tle, przynajmniej jako kryteria, chociaż są uwzględnione w narracji Noltego i na pewno ilustrują mechanizmy przymusu wywieranego przez cesarską władzę ${ }^{18}$. W ten sposób Nolte odróżnia się od Jane Burbank i Frederica Coopera, którzy mocniej podkreślali zdolność imperium do zarządzania różnicami kulturowymi i raczej nie uwzględniają ucisku i przymusu.

Monarchia habsburska jest o wiele skromniej reprezentowana w dyskusji o imperiach, jak to oczekiwałoby się z środkowoeuropejskiej perspektywy. Należy podkreślić, że użycie terminu „imperium” na określenie monarchii habsburskiej wywodzi się przede wszystkim z badań anglosaskich. Warto wspomnieć tutaj o Robercie Kannie, ${ }^{19}$ Carlile Aylmer Macartney ${ }^{20}$ lub Robercie Evansie ${ }^{21}$. Badacze austriaccy

\footnotetext{
13 J. Osterhammel, Verwandlung, s. 565-672.

14 J. Burbank, F. Cooper, Empires in world history. Power and the politics of difference, Princeton 2010.
}

15 Imperien und Reiche in der Weltgeschichte - Epochenübergreifende und globalhistorische Vergleiche, red. M. Gehler, R. Rollinger, Wiesbaden 2014.

16 H. Münkler, Imperien. Die Logik der Weltherrschaft - vom Alten Rom bis zu den Vereinigten Staaten, Berlin 2005.

17 H.-H. Nolte, Kurze Geschichte der Imperien. Mit einem Beitrag von Christiane Nolte, Wien-Köln-Weimar 2017.

18 Tamże, s. 41-43.

19 R.A. Kann, A History of the Habsburg Empire 1526-1918, Berkeley-Los Angeles-London 1974.

20 C.A. Macartney, The Habsburg Empire 1790-1918, London 1968.

21 R.J. W. Evans, The making of the Habsburg monarchy 1550-1700, Oxford 1984; tenże, Austria, Hungary, and the Habsburgs: essays on Central Europe, 1683-1867, Oxford 2006. 
zastosowali koncepcję imperium w projekcie pt. „Habsburg postcolonial”, który rozpoczęto na początku XX w. Była to krytyczna rewizja historii imperium Habsburgów z perspektywy studiów postkolonialnych. Szczególny nacisk położono na misję cywilizacyjną, jak również na kontrast między centrami a peryferiami oraz na kwestię tożsamości narodowej i imperialnej aż po tożsamość hybrydową ${ }^{22}$.

W przeciwieństwie do tych badań amerykański historyk i ekspert historii Habsburgów Pieter Judson opublikował niedawno nową historię imperium Habsburgów ${ }^{23}$. Główne argumenty Judsona kwestionują tradycyjną narrację o zacofanej monarchii. Przeciwstawia on tej narracji udany proces centralizacji i formowania się państwa od czasu oświeconego despotyzmu Marii Teresy i Józefa II w drugiej połowie XVIII w. Ten okres reform był podstawą liberalnego imperium, które powoli wyłaniało się od rewolucji 1848 r. aż do przekształcenia się w dualistyczną formę Austro-Węgier w 1867 r. Judson twierdzil, że w tej późnej fazie monarchii antagonizmy narodowe są przeszacowane. Amerykański historyk interpretuje te konflikty raczej jako wynik polityki nacjonalistycznej niewielkich grup a nie jako antagonizmy narodowościowe obejmujące całe społeczeństwa. W ten sposób można zdekonstruować tzw. antagonizmy narodowe przez samo umieszczenie ich w kontekście społecznym i politycznym. Ale Judson idzie krok dalej. Twierdzi, że narody wykształciły się jako takie w XIX w., jako grupy i posiadały wspólną tożsamość zbudowaną na podstawie politycznego równouprawnienia. Uważa również, że powstanie i konsolidacja narodów były odpowiedzią na kwestionowanie praw kulturalnych poszczególnych grup narodowych przez imperia.

Tym tezom można poświęcić wiele uwagi ${ }^{24}$. W kontekście poruszanych w artykule problemów ograniczę się jednak do wskazania, że podejście Judsona zawiera wiele nowych elementów i stanowi bardzo produktywną interpretację historii Habsburgów. W swojej książce autor nie poświęca wiele miejsca procesom gospodarczym, podobnie jak regionalnym różnicom w rozwoju i wynikającym stąd konfliktom. Ogólnie rzecz biorąc, podobnie jak w przypadku Burbank i Coopera, także w odniesieniu do książki Judsona, można stwierdzić, że znalezienie zrównoważonej

22 Habsburg postcolonial. Machtstrukturen und kollektives Gedächtnis, red. J. Feichtinger, U. Prutsch, M. Csáky, Innsbruck 2003; Schauplatz Kultur - Zentraleuropa. Transdisziplinäre Annäherungen, red. J. Feichtinger, Innsbruck 2006.

23 P.M. Judson, The Habsburg Empire. A new history, Cambridge 2016 (w języku polskim opublikowana jako: Imperium Habsburgów. Wspólnota Narodów, Warszawa 2017).

24 Dla oceny pracy Judsona można wskazać szereg recenzji. Tutaj odnoszę się do recenzji, którą opublikowałem zarazem z Oliverem Kühschelmem: K. Kaps, O. Kühschelm, Unser tägliches Reich gib uns heute?, Österreichische Zeitschrift für Geschichtswissenschaft 29 (2018), 3, s. 228-244. 
oceny pomiędzy imperialnymi, narodowymi i nacjonalistycznymi mechanizmami przymusu jest dużym wyzwaniem.

Kontekst imperialny ma oczywiście wpływ na proces rozwoju gospodarczego. $\mathrm{Z}$ jednej strony gdyż prawodawstwo, polityka administracyjna i egzekutywa stanowiły silny impuls dla rozwoju rynku wewnętrznego imperium, ${ }^{25} \mathrm{z}$ drugiej strony, ponieważ imperium było punktem odniesienia dla środków polityki gospodarczej takich jak infrastruktura, edukacja, polityka celna i podatkowa ${ }^{26}$. Środki te były negocjowane w procesie politycznym, w najszerszym tego słowa znaczeniu, mimo że do okresu konstytucyjnego po $1861 \mathrm{r}$. zgromadzenia stanowe (instytucje w skład których wchodzili przedstawiciele elit poszczególnych prowincji) formalnie miały coraz mniej wplywu na decyzje rządu centralnego, a arystokracja znacząco, acz nieformalnie, oddziaływała na tę politykę ${ }^{27}$. Podczas gdy jest rzeczą oczywistą, że sfera gospodarcza wiązała się z kwestiami politycznymi, należy uwzględnić także inne aspekty życia społecznego, takie jak rozwarstwienie społeczne lub status społeczny, normy kulturowe i tożsamość narodową ${ }^{28}$.

\section{Imperialny region pograniczny. Galicja jako produkt polityki Habsburgów}

W przypadku Galicji te ogólne ramy polityki imperialnej mają szczególne znaczenie, ponieważ prowincję tę, a później od 1861 r. kraj koronny, należy traktować jako typowy twór imperialnego myślenia i działania. Było to bardziej wyraźne niż w przypadku innych części monarchii, z wyjątkiem Bośni i Hercegowiny. Udział monarchii w pierwszym rozbiorze Rzeczpospolitej Obojga Narodów (Polski i Litwy) był nie tylko naruszeniem dyplomatycznych i geopolitycznych tradycji wiedeńskiego dworu, ale także punktem zwrotnym dla wewnętrznej konfiguracji monarchii. Zamiast

\footnotetext{
25 A. Komlosy, Grenze, s. 133-145.

26 H. Matis, Leitlinien der österreichischen Wirtschaftspolitik, [w:] Die Habsburgermonarchie 1848-1918, t. I, Die wirtschaftliche Entwicklung, red. A. Brusatti, Wien 1973, s. 29-67; J. Wysocki, Infrastruktur und wachsende Staatsausgaben. Das Fallbeispiel Österreich 1868-1913, Stuttgart 1975.

27 R.A. Krueger, Mediating Progress in the Provinces: Central Authority, Local Elites, and Agrarian Societies in Bohemia and Moravia, Austrian History Yearbook 35 (2004), s. 49-79.

28 Identitätenwandel und nationale Mobilisierung in Regionen ethnischer Diversität. Ein regionaler Vergleich zwischen Westpreußen und Galizien am Ende des 19. und Anfang des 20. Jahrhunderts, red. R. Schattkowsky, Marburg 2004.
} 
dynastycznych uzgodnień, np. poprzez sojusze małżeńskie, które uzasadniały roszczenia do historycznie powstałych terytoriów europejskich ${ }^{29}$, monarchia habsburska w przypadku zajęcia Galicji posłużyła się zasadą racji stanu i większymi zasobami władzy, a przede wszystkim siłą militarną i możliwościami fiskalnymi ${ }^{30}$. Naturalnie przy pomocy owych środków zwyczaj integrowano wcześniej także już istniejące jednostki przestrzenne z państwem Habsburgów, niezależnie, czy odnosi się to do królestw (jak w przypadku Czech i Węgier), do księstw (jak w przypadku Karyntii, Mediolanu czy Mantui), czy hrabstw (jak w przypadku Tyrolu) ${ }^{31}$. Jednak w przypadku Galicji stworzono nową przestrzeń, proces, który Larry Wolff określił jako „wynalezienie Galicji” ${ }^{2}$. Próby ukrycia sztucznego charakteru Galicji przez podniesienie roszczeń korony węgierskiej do Królestwa Halicza i czeskiej do księstw Oświęcimia i Zatoru w latach $1772-1773$ były mało wiarygodne ${ }^{33}$. Formalnie te roszczenia, które wywodzono z późnego średniowiecza, nie tylko dawno wygasły, ale nie grały prawie żadnej roli w ostatecznym uzgodnieniu granicy demarkacyjnej z Rzeczpospolitą w 1776 r. Nawet oficjalna nazwa Galicji i wytyczona dla niej przestrzeń pokrywała się tylko częściowo z terytorium dawnego Królestwa Halicza ${ }^{34}$. Co więcej, dyskurs ten był skierowany przede wszystkim do mocarstw zachodnioeuropejskich, czego

29 C. Ingrao, The Habsburg Monarchy 1618-1815, Cambridge 2000, s. 2-6.

30 S. Grodziski, Historia ustroju społeczno-politycznego Galicji 1772-1848, Wrocław-Warszawa-Kraków-Gdańsk 1971, s. 6, 26; K.A. Roider, Austria's eastern question, 1700-1790, Princeton 1982; K. Vocelka, Glanz und Untergang der höfischen Welt. Repräsentation, Reform und Reaktion im Habsburgischen Vielvölkerstaat (Österreichische Geschichte von 1699-1815, red. H. Wolfram, t. 8), Wien 2001, s. 98; Rezolucja Marii Teresy, Laxenburg z 15 IX 1772, Haus-, Hof- und Staatsarchiv (dalej: HHStA), Kabinettsarchiv (dalej: KA), Staatskanzlei, jednostka 110 (Vorträge VIII-XII), IX-X, fol.287.

31 K. Vocelka, Geschichte Österreichs. Kultur - Gesellschaft - Politik, Graz-Wien-Köln 2002, s. 64-71, 95-99.

32 L. Wolff, Inventing Galicia: Messianic Josephinism and the Recasting of Partitioned Poland, Slavic Review 63 (2004), z. 4, s. 818-840.

33 S. Grodziski, Historia, s. 26; D. Gawrecki, Schlesien als Randgebiet der Habsburgermonarchie nach 1742, [w:] H.-C. Maner, Grenzregionen, s. 136; K.K. Daszyk, Eroberer oder Anwärter auf den polnischen Thron. Die Habsburger im Urteil und den politischen Plänen der Polen in der Zeit der Teilungen (1772-1795), [w:] Österreich - Polen 1000 Jahre Beziehungen, Studia Austro-Polonica, t. 5, red. J. Buszko, W. Leitsch, Kraków 1996, s. 133 i n.

34 L. Haczynski, Two Contributions to the Problem of Galicia, East European Quarterly 4 (1970), 1, s. 94 n. A.V. Wendland, Galizien: Westen des Ostens, Osten des Westens, Österreichische Osthefte 42 (2000), 3-4, s. 389-421. 
dowodzi fakt, że memorandum, w którym wyjaśniono historyczne roszczenia ${ }^{35}$, było rozpowszechnione poprzez ambasady imperialne w Londynie, Paryżu i Madrycie ${ }^{36}$. Także ambasador Republiki Genui w Wiedniu otrzymał egzemplarz i przesłał go swoim mocodawcom ${ }^{37}$.

Dużo bardziej istotny dla ustanowienia panowania Habsburgów w Galicji był jednak dość intensywny dyskurs cywilizacyjny, który konsekwentnie negatywnie oceniał polityczne, gospodarcze i społeczne struktury Rzeczpospolitej w celu uzyskania legitymizacji własnej władzy ${ }^{38}$. Porównania Galicji z Meksykiem, „El Dorado” i Peru a również ogólnie z koloniami hiszpańskimi w Ameryce, Indiami i Syberią w tym okresie, podkreślają przypisanie jej drugorzędnej rangi w hierarchii przestrzennej i politycznej monarchii habsburskiej, co również miało usprawiedliwić włączenie tego obszaru ${ }^{39}$. Proces ten zbiegł się z okresem oświeceniowych reform w imperium Habsburgów, które rozpoczęły się w 1748 r. Reformy te osiągnęły swój szczytowy punkt za panowania Józefa II (1780-1790) ${ }^{40}$. Topos Galicji jako „kra-

35 Vorläufige Ausführung der Rechte des Königreichs Hungarn auf Klein oder Roth Reussen und Podolien und des Königreichs Böheim auf die Herzogthümer Auschwitz und Zator, 1773. 36 Vortrag vom 15 IX 1772, HHStA, KA, Staatskanzlei, Karton nr 110, X, fol. 72-79. Vortrag Wienn den 10ten Novembris 1772. Zu einigen Abdrücken der in Lateinische und Teutschen Sprach Verfaßten Vorläufigen Deduction d Königl-Hungars. Ansprüche auf Klein oder Rothreussen, und Podolien, dann d k. Böhm. Gerechtsahmen auf die Herzigthümer Auschwiz [sic] und Zator, welche nach Meynung Celsifu nunmehro in das publicum zu verbreiten wäre, HHStA, KA, Staatskanzlei, Karton nr 110, XI, fol. 26-27, 217.

37 List Giuseppe d'Oria z 9 I 1773, Archivio di Stato di Genova (dalej ASG), Archivio Segreto, jednostka nr 2603, anno 1773, nr 162.

38 L. Wolff, Inventing Galicia; H.-C. Maner, Galizien. Eine Grenzregion im Kalkül der Donaumonarchie im 18. und 19. Jahrhundert, München 2007, s. 11, 35, 38-42; Р. Голик,"Галичина" як семіотична проблема: Ао археології образів та стереотипів, [w]: Confraternitas. Ювілейний збірник на пошану Ярослава Ісаєвича, Україна: Култура Спадщина, Національна Свідомість, Аержавність 15, red. Національна Академіа Наук України - Інститут Українознавства ім. І. Крип'якевича,

39 H.A. Traunpaur, Dreyssig Briefe über Galizien oder - Beobachtungen eines unpartheyischen Mannes, der sich mehr als nur ein paar Monate in diesem Königreiche umgesehen hat, Wien-Leipzig 1787, s. 66; B. Hacquet, Hacquets neueste physikalisch-politische Reisen, 1788-1793, Zweyter Theil, Nürrnberg 1791, s. 192; S. Bredetzky, Historisch-statistischer Beytrag zum deutschen Kolonialwesen in Europa, nebst einer kurzen Beschreibung der deutschen Ansiedlungen in Galizien in alphabetischer Ordnung, Brünn 1812, s. 22; A. Beer, Die österreichische Handelspolitik unter Maria Theresia und Joseph II., Archiv für Österreichische Geschichte 86 (1899), s. 90-93.

40 C. Ingrao, Habsburg Monarchy, s. 159-172, 178-192. 
ju modelowego” lub „pola doświadczalnego” tych reform wyjaśnia ${ }^{41}$, że chodziło nie tylko o integrację Galicji z dotychczas istniejącymi ramami instytucjonalnymi i normatywnymi monarchii habsburskiej, ale też o nową definicję zasad i praktyk funkcjonowania całego państwa.

Włączenie Galicji w rozważania centrum politycznego - Wiednia, odzwierciedlało się również w niepewnej przynależność tej prowincji jako jednostki terytorialnej. Potwierdzają to nie tylko plany wymiany Galicji na inne obszary ${ }^{42}$, lecz przede wszystkim liczne zmiany jej granic. Przypomnieć tu trzeba krótkotrwałą zdobycz, tak zwaną Galicję Zachodnią zajętą w trzecim rozbiorze Polski, chwilową utratę Tarnopola na rzecz Rosji i trwałą utratę Zamościa po 1809 r. oraz aneksję Rzeczpospolitej Krakowskiej w 1846 r. czy wreszcie tymczasowe oddzielenie od Galicji Oświęcimia i Zatoru oraz integrację tych księstw ze Śląskiem Cieszyńskim ${ }^{43}$, Galicja była również przewidywanym teatrem działań wojennych w planach rozmieszczenia armii cesarskiej aż do rewolucji w 1848 r. Dopiero później, po kompromisie austro-węgierskim w 1867 r. w planach wojennych uwzględniono konieczność obrony jej granic, decydując się na utworzenie ważnej twierdzy w Przemyślu ${ }^{44}$.

\section{Ograniczona władza w dwóch kierunkach. Splot procesów poli- tycznych i gospodarczych między Wiedniem i Galicją}

Choć pod wieloma względami panowanie Habsburgów w Galicji było punktem zwrotnym, możliwości ingerencji imperialnego centrum w stosunki galicyjskie były ograniczone. Opór szlachty, zwłaszcza średniej, i magnaterii uniemożliwił dogłębną centralizację. Można w tym kontekście wspominać o sojuszu szlachty z Prusami na przełomie 1789 i 1790 r., kiedy to planowano wspólne działania przeciw państwu habsburskiemu ${ }^{45}$. Po wojnach napoleońskich, krótkotrwałym ustanowieniu Księ-

41 K.K. Daszyk, Eroberer, s. 141; H.-C. Maner, Zwischen „Kompensationsobjekt, „Musterland” und "Glacis”. Wiener politische und militärische Vorstellungen von Galizien von 1772 bis zur Autonomieära, [w:] tenże, Grenzregionen, s. 112; H. Glassl, Das Österreichische Einrichtungswerk im Galizien, 1772-1790, Wiesbaden 1975, s. 11.

42 H.-C. Maner, Galizien, s. 59.

43 L. Haczynski, Two contributions, s. 96-99.

44 H.-C. Maner, Kompensationsobjekt, s. 105, 116; Tenże, Galizien, s. 190-212; M. Zgórniak, Galizien in den Kriegsplänen Österreichs und Österreich-Ungarns, [w:] J. Buszko, W. Leitsch, Österreich - Polen, s. 300.

45 K.K. Daszyk, Eroberer, s. 144 n. 
stwa Warszawskiego i Królestwa Polskiego, misja cywilizacyjna w końcu zatrzymała $\operatorname{się}^{46}$. Do fazy konstytucyjnej w dziejach państwa Habsburgów i sojuszu między polską szlachtą a cesarskim tronem wiodła jeszcze długa droga prowadząca przez Rabację w 1846 r. oraz rewolucyjne wydarzenia Wiosny Ludów dwa lata później ${ }^{47}$. Ale to właśnie owe przemiany władzy cesarstwa habsburskiego wpłynęły na status Galicji.

Znaczenie galicyjskich elit w politycznym centrum państwa - Wiedniu, wzrosło wraz z częściową demokratyzacją i federalizacją zachodniej części monarchii, tzw. Przedlitawi po $1867 \mathrm{r}^{48}$ Znalazło to swój wyraz również w zwiększeniu wpływu galicyjskich elit na środki polityki gospodarczej. Warunkiem była oczywiście zmiana stosunku szlachty do przedsiębiorczości. W tej transformacji ważną rolę odegrało uwłaszczenie, które zostało przeprowadzone w czasie rewolucji $1848 \mathrm{r}^{49}$

Ważnym punktem było także pojawienie się nowych warstw społeczeństwa, zwłaszcza burżuazji, ale także robotników przemysłowych i samodzielnie gospodarujących chłopów, którzy mogli mieć wpływ na dyskurs polityki gospodarczej ${ }^{50}$.

46 H.-C. Maner, Galizien, s. 113 n.

47 Tamże, s. 135.

48 H. Binder, Galizien in Wien. Parteien, Wahlen, Fraktionen und Abgeordnete im Übergang zur Massenpolitik, Wien 2005; tenże, „Galizische Autonomie” - ein streitbarer Begriff und seine Karriere, [w:] Moravské vyrovnání zroku 1905 / Der Mährische Ausgleich von 1905, red. L. Fasora, Brünn - Brno 2006, s. 239-266; D. Szymczak, Galicyjska „ambasada” w Wiedniu. Dzieje ministerstwa dla Galicji 1871-1918, Poznań 2013.

49 K. Ślusarek, Uwłaszczenie chłopów w Galicji zachodniej, Kraków 2002; Tenże, Sytuacja szlachty i chtopstwa na tle przemian struktury społeczeństwa polskiego w XIX wieku, [w:] Problemy cywilizacyjnego rozwoju Białorusi, Polski, Rosji i Ukrainy od końca XVIII do XXI wieku, red. P. Franaszek, A.N. Nieczuchrina, Kraków 2007, s. 292-298; A. Заярнюк, Iдіоми емансипації. «Визвольні» проєкти і галицьке село в середині XIX століття, Київ 2007. 50 T. Kargol, Izba Przemystowa-Handlowa $w$ Krakowie w latach 1850-1939. Dzieje - ludzie - polityka gospodarcza, Kraków 2003; Tenże, Zieleniewscy, Baczewscy, Grossowie... Galicyjscy przedsiębiorcy $w$ drugiej potowie XIX wieku (do 1914 r.) - kierunki badań i postulaty badawcze, Kwartalnik Historyczny CXVI (2009), z. 2, s. 197-217; F. Kiryk, H. Żaliński, Zieleniewscy. Z dziejów kształtowania się burżuazji krakowskiej, [w:] Dzieje burżuazji w Polsce. Studia i Materiały, t. III, red. R. Kołodziejczyk, Wrocław 1983, s. 267-292; L. Kuberski, Stanistaw Szczepanowski 1846-1900. Przemystowiec, Polityk, Publicysta, Opole 1997; A. Burzynski, Robotnicy $w$ przemyśle ciężkim $w$ Galicji $w$ dobie autonomicznej. Struktura zatrudnienia, Wroclaw 1985; J. Buszko, Zum Wandel der Gesellschaftsstruktur in Galizien und in der Bukowina, Wien 1978, s. 10, 12; A. Frank Fleig, Oil Empire. Visions of Prosperity in Austrian Galicia, Cambridge 2007, s. 75-139; J.-P. Himka, Socialism in Galicia. The Emergence of Polish Social Democracy and Ukrainian Radicalism (1860-1890), Cambridge 1983; tenże, Galician Villagers and the Ukrainian National Movement in the Nineteenth Century, Basingstoke 1988; 
W tym przypadku należy wziąć pod uwagę nie tylko różnice społeczne w zakresie celów i dążeń polityki gospodarczej, ale także ściśle z tym powiązane kulturowe i coraz bardziej postępujące narodowe (tworzenie się nowoczesnych narodów) rozdrobnienie społeczeństwa galicyjskiego.

W ten sposób można określić występowanie zarówno wspólnych, jak i silnie rozbieżnych interesów w zależności od środowiska społeczno-gospodarczego i kulturowego. Doskonałą ilustracją dla tych procesów są przykłady sytuacji, w których polscy i żydowscy przedsiębiorcy w sektorze przemysłowym i rzemieślniczym mogli mieć wspólne interesy. Mogły to być niskie podatki korporacyjne i w niektórych przypadkach protekcjonistyczna albo liberalna polityka celna ${ }^{51}$.

Natomiast brakowało tego porozumienia, jeżeli chodziło o interesy rolnictwa. O ile wypracowanie wspólnego stanowiska w sprawie polityki celnej było możliwe, o tyle poglądy na temat obciążeń podatkowych zasadniczo różniły szlachtę i chłopów $^{52}$. Jeszcze bardziej wyraźne rozbieżności występowały pomiędzy polskimi i żydowskimi przedsiębiorcami, gdy chodziło o obrót produktów rolnych z wykorzystaniem spółdzielni, tak zwanych „Kółek Rolniczych”. Od lat osiemdziesiątych XIX w. szlachta i chłopi stali się konkurencją dla przedsiębiorstw warstwy średniej, często należących do właścicieli żydowskich. Ten pozornie społeczny konflikt przekształcił się w kulturalno-narodowy, gdy polscy chłopi i szlachta zjednoczyli się przeciwko żydowskim przedsiębiorstwom. Podobnie miało to miejsce w stosunku do rusińskich lub ukraińskich chłopów w Galicji Wschodniej. Jednak ogólnie rzecz biorąc ruch spółdzielczy nie mógł wypchnąć żydowskich kupców i właścicieli sklepów $\mathrm{z}$ ich miejsca w sektorze chociaż, oczywiście, ograniczały zyski ${ }^{53}$. Konflikt w Galicji Wschodniej miał jednak jeszcze bardziej złożony charakter z powodu antagonizmu między ukraińskimi chłopami a polską szlachtą, za którym stały względy polityczne,

K. Jobst, Zwischen Nationalismus und Internationalismus. Die polnische und ukrainische Sozialdemokratie in Galizien von 1890 bis 1914. Ein Beitrag zur Nationalitätenfrage des Habsburgerreichs, Hamburg 1996; S. Hryniuk, Peasants with Promise. Ukrainians in South-Eastern Galicia 1880-1900, Edmonton 1991.

51 Zob. dla takich przykładów: Handelskammer Lemberg, Sitzungsprotokolle 1890-92.

52 J. Buszko, Wandel, s. 8.

53 T. Andlauer, Die jüdische Bevölkerung im Modernisierungsprozess Galiziens (1867-1914), Frankfurt/Main-Wien 2001, s. 247; S. Tokarski, Ethnic conflict and development. Jews in Galician agriculture (1868-1914), Warszawa 2003, s. 48, 157, 172 n, 175; K. Stauter-Halsted, The Nation in the Village. The Genesis of Peasant National Identity in Austrian Poland, 1848-1914, Ithaca-London 2001, s. 134-139; K. Struve, Bauern und Nation in Galizien. Über Zugehörigkeit und soziale Emanzipation im 19. Jahrhundert, Göttingen 2005, s. $12,14$. 
ale również nacjonalistyczna agitacja uprawiana przez obie strony ${ }^{54}$. Z drugiej strony na początku XX w. syjonistyczni żydowscy pracownicy branży handlowej z wschodniogalicyjskiego Bolechowa skarżyli się na sojusz żydowskich finansistów z polską szlachtą, gdy chodziło o zakładanie banków ${ }^{55}$.

\section{Gospodarka, tożsamości kulturowo-narodowe, etnizacja. Eko- nomiczne sploty i mechanizmy konkurencji w wielokulturo- wym społeczeństwie}

Powyższe przykłady ilustrują nie tylko związek między rozwojem gospodarczym a etniczno-narodowym rozdrobnieniem społeczeństwa ${ }^{56}$. Dodatkowo podkreślają ogólne rozłamy dokonujące się w społeczeństwie galicyjskim pod koniec XIX w. Podczas gdy dotychczasowy dorobek historiografii skupiał się na identyfikacji wyraźnych narodowych procesów demarkacyjnych, ${ }^{57}$ codzienne życie podmiotów jako znacznie bardziej złożone, przykuwało mniej uwagi. Tymczasem demarkacja międzyetniczna współistniała ze współpracą międzyetniczną. Warstwy społeczne i tożsamość kulturowo-narodowa były ze sobą związane ${ }^{58}$. Wyjątkowość tego zjawiska nie została choćby powierzchownie odzwierciedlona nawet $w$ najlepszych i teoretycznie i metodologicznie innowacyjnych narodowych narracjach historycznych ${ }^{59}$. To już

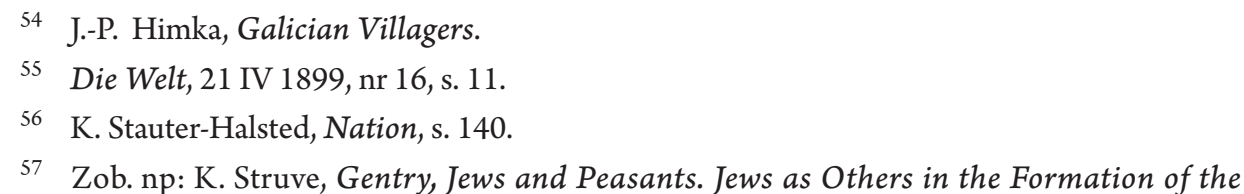
Modern Polish Nation in Rural Galicia during the Second Half of the Nineteenth Century, [w:] Creating the Other. Ethnic Conflict and Nationalism in Habsburg Central Europe, red. N. Wingfield, New York 2003, s. 103-126; S. Tokarski, Ethnic conflict. J.-P. Himka, Galician Villagers; R. Schattkowsky, Identitätenwandel und nationale Mobilisierung in Westpreußen und Galizien. Ein Vergleich, [w:] tenże, Identitätenwandel, s. 29-62; G.B. Cohen, Nationalist Politics and the Dynamics of State and Civil Society in the Habsburg Monarchy, 1867-1914, Central European History 40 (2007), nr 2, s. 241-278.

58 K. Struve, Bauer und Nation, s. 12, 14, 19, 23, 90; J. Zawistowski, Problemy narodowościowe w ruchu zawodowym, [w:] Galicyjskie dylematy. Zbiór rozpraw, red. K. Karolczak, H.W. Żaliński, Kraków 1994, s. 50-56; J. Holzer, Enlightenment, Assimilation, and Modern Identity: The Jewish Elite in Galicia, [w:] Focusing Galicia: Jews, Poles and Ukrainians, 1772-1918, Polin t. 12, Studies in Polish Jewry, red. I. Bartal, A. Polonsky, London 1999, s. 79-85 .

59 Zob np.: A. Chwalba, Historia Polski 1795-1918, Kraków 2005; J.-P. Himka, Galician Villagers; Y. Hrytsak, Historic Memory and Regional Identity among Galicia's Ukrainians, [w:] 
wskazuje drogę do skomplikowanego problemu złożonych tożsamości, które nie wykluczały równoczesnej identyfikacji z narodem, z krajem koronnym Galicją, a też z cesarzem w Wiedniu, jak zostało to ukazane w studiach postkolonialnych. Różne motywacje poszczególnych podmiotów i ich środowisk, żeby posiadać więcej niż jedną tożsamość, podlegały oczywiście zmianom i były silnie skontekstualizowane ${ }^{60}$.

Idąc tym tropem można wskazać na konflikt geopolityczny z Rosją, który wywoływał u wielu polskich czynników politycznych w drugiej połowie XIX w. uświadomienie konieczności zbliżenia się do tronu Habsburgów ${ }^{61}$. Wielu Żydów uznało wartość rządowych wysiłków emancypacyjnych w Przedlitawii okresu konstytucyjnego, a polscy i ukraińscy chłopi doceniali wyzwolenie od pańszczyzny, chociaż krytykowali opłaty indemnizacyjne i utratę tzw. serwitutów, czyli możliwości dostępu do lasów i pastwisk. Z tego też powodu jeszcze na początku okresu konstytucyjnego w 1866 r. większość rusińskich i polskich chłopów z wielkim sceptycyzmem podchodziła do działalności Sejmu krajowego galicyjskiego, obawiając się powrotu do jednostronnej dominacji szlacheckiego ziemiaństwa ${ }^{62}$. Niniejsze konstatacje nie powinny przesłaniać faktu, że stopniowo narastające antagonizmy narodowe przed pierwszą wojną światową były wzmocnione przez niepewny rozwój gospodarczy Galicji. Wiele regionalnych i lokalnych konfliktów dotyczących ograniczonych za-

Galicia. A Multicultured Land, red. C. Hann, P.R. Magocsi, Toronto-Buffalo-London 2005, s. 185-209; H. Rumpler, Eine Chance für Mitteleuropa. Bürgerliche Emanzipation und Staatsverfall in der Habsburgermonarchie. Österreichische Geschichte 1804-1914, Wien 1997.

60 H. Uhl, Zwischen „Habsburgischem Mythos” und (Post-)Kolonialismus. Zentraleuropa als Paradigma für Identitätskonstruktionen in der (Post-)Moderne, [w:] Habsburg postcolonial. Machtstrukturen und kollektives Gedächtnis, red. J. Feichtinger, U. Prutsch, M. Csáky, Innsbruck 2003, s. 45-54. W odniesieniu do Galicji zob.: K. Stauter-Halsted, Nation, s. 8-9; D. Sosnowska, Inna Galicja, Warszawa 2008; A.V. Wendland, Eindeutige Bilder, komplexe Identitäten. Imperiale, nationale, regionale Identitätskonzepte und ihre Visualisierung auf der galizischen Allgemeinen Landesausstellung in Lemberg 1894, Zeitschrift für Ostmitteleuropaforschung 58/1-2 (2009), s. 111-161; S. Simonek, Franko, Mickiewicz, Bahr - rodzaje galicyjskiej subalternacji okoto roku 1900, Historyka. Studia metodologiczne XLII (2012), s. $147-158$.

61 K.K. Daszyk, Między polską racją stanu a habsburskim mitem. Dom Habsburgów w galicyjskiej myśli politycznej doby autonomicznej, [w:] Galicja i jej dziedzictwo, t. I: Historia i polityka, red. W. Bonusiak, Rzeszów 1994, s. 72; H.-C. Maner, Galizien, s. 115.

62 J. Buszko, The Consequences of Galician Autonomy after 1867 [w:] Focusing Galicia: Jews, Poles, s. 86-99; A. Kappeler, Kleine Geschichte der Ukraine, München 2000, s. 124, 126; K. Struve, Bauern und Nation, s. 101, 104, 107 n, 110 n, 118 n; P. Wróbel, The Jews under Austrian-Polish Rule, 1869-1918, Austrian History Yearbook 25 (1994), s. 97-138. 
sobów było w dużej mierze spowodowanych brakiem uprzemysłowienia i znacząco opóźnionym początkiem wzrostu wydajności w sektorze rolnym ${ }^{63}$.

$\mathrm{W}$ połączeniu $\mathrm{z}$ ambiwalentnym postrzeganiem zewnętrznych podmiotów gospodarczych i przedsiębiorstw jako niezbędnych inwestorów z jednej strony i niepożądaną konkurencję na galicyjskim rynku z drugiej strony ${ }^{64}$ często motywowany społeczno-ekonomicznie gniew kierowany był przeciwko pozornym winowajcom tych problemów gospodarczych.

Należeli do tej grupy niewątpliwie żydowscy kupcy, a zwłaszcza drobni handlarze i domokrążcy. Byli oni ulubionymi celami oskarżeń i krytyki, które w narastającym stopniu nabierały charakteru antisemickiej propagandy, co miało przyczyny ekonomiczne, społeczne i kulturowe ${ }^{65}$. Ta etnizacja gospodarki hamowała i utrudniała skuteczne dostosowanie polityki gospodarczej do przemian na szczeblu regionalnym i międzynarodowym. Rozsądne rozwiązania zostały utrudnione poprzez dominację narodowych interesów politycznych. Dotychczas panująca antyteza między imperium a regionem jako narodem została wyparta przez wewnętrzno-regionalne antagonizmy między krajowymi grupami narodowymi. Niemniej trzeba ponownie wyraźnie podkreślić, że nie była to jedyna tendencja rozwojowa. Wciąż było wystarczająco dużo nisz i przestrzeni dla międzykulturowej współpracy i interakcji. W tym kontekście Sławomir Tokarski przekonywał, że antysemicka propaganda ruchu spółdzielczego nie mogła doprowadzić do zniesienia równouprawnienia ludności żydowskiej w konstytucji Przedlitawii z 1867 r. ${ }^{66}$ Twierdzenie autora, że obawy kupców żydowskich przed sparaliżowaniem ich działalności gospodarczej przez organizacje spółdzielcze były bezpodstawne ${ }^{67}$, można jednak skonfrontować $\mathrm{z}$ faktem, że tendencje etnizacyjne

63 A. Kappeler, Geschichte, s. 128; K. Struve, Peasant Emancipation and National Integration. Agrarian Circles, Village Reading Rooms, and Cooperatives in Galicia, [w:] Cooperatives in Ethnic Conflicts: Eastern Europe in the 19th and early 20th Century (Frankfurter Studien zur Wirtschafts- und Sozialgeschichte Ostmitteleuropas, tom 15), red. T. Lorenz, Berlin 2006, s. 229-250.

64 M. Dylewski, Jak u nas dźwignać rolnictwo, przemyst, komunikacye, koleje, Drohobycz-Lwów 1868, s. 9; T. Rutowski, $W$ sprawie przemystu krajowego, Kraków 1883, s. 10; Praca III/21, 10 XII 1864 s. 1; J.-P. Himka, Socialism in Galicia, s. 15 n.

65 S. Tokarski, Ethnic conflict, s. 51, 174 n; K. Kaps, Peripherisierung der Ökonomie, Ethnisierung der Gesellschaft: Galizien zwischen äußerem und innerem Konkurrenzdruck. (1856-1914), [w:] Galizien. Fragmente eines diskursiven Raums, red. DK Galizien, Innsbruck 2009, s. 37-62.
66 S. Tokarski, Ethnic conflict, s. 51.
67
Tamże, s. $174 \mathrm{n}$. 
w gospodarce galicyjskiej wzrastały do pierwszej wojny światowej i nabrały zarówno form przemocy (fala pogromów w Galicji Zachodniej w 1898 r. i ponownie w 1903 r.), jak i również bojkotu gospodarczego (apele ogłaszane przez zgromadzenie katolickie w 1893 r. i przyjęte w późniejszych latach również przez PSL oraz rzeczywiście zorganizowany przez endecję w 1909 r. i 1912 r. bojkot) ${ }^{68}$, na co Tokarski nie zwrócił należytej uwagi, jako na fenomeny wpływające na stosunki społeczno-gospodarcze w tym okresie. W konkluzji można więc stwierdzić, że narodowe, a nawet nacjonalistyczne linie demarkacyjne nabierały przed wybuchem pierwszej wojny światowej $\mathrm{w}$ coraz większym stopniu znaczenia dla definiowania interakcji pomiędzy różnymi środowiskami społeczno-kulturowym w Galicji.

\section{Międzyregionalny podział pracy w imperium. Wymiana towaro- wa, perspektywy rozwojowe a polityka celno-handlowa}

Peryferyjną sytuację rozwoju gospodarczego Galicji należy skontekstualizować w perspektywie czasowej, jak i także w stosunku do regionalnego podziału pracy i polityki imperialnej. Spoglądając z perspektywy tzw. logue durée, czyli długiego trwania Fernanda Braudela ${ }^{69}$, można stwierdzić, że względny udział Galicji w dochodach zachodnich krajów koronnych Habsburgów od 1785 do 1913 r. pozostawał prawie cały czas na stałym niskim poziomie ${ }^{70}$. Strukturalna zmiana w Galicji była bardzo powolna i rozpoczęła się późno. Nawet po rewolucji w 1848 r., 88 procent ludności pracowało w rolnictwie, a udział ten spadł do $74 \%$ przed pierwszą wojną światową. W tym czasie w regionach uprzemysłowionych mniej niż jedna trzecia ludności pracowała w rolnictwie ${ }^{71}$. Brakowało też możliwości przekształcenia przedsiębiorstw rzemieślniczych istniejących pod koniec XVIII w., w szczególności

\footnotetext{
68 K. Struve, Bauern und Nation, s. 426-429; P. Wróbel, Jews of Galicia, s. 119, 131; T. Buchen, Antisemitismus in Galizien. Agitation, Gewalt und Politik gegen Juden in der Habsburgermonarchie um 1900 (=Studien zum Antisemitismus in Europa, tom 3), Berlin 2012, s. 167-237; R. Wapiński, The Endecja and the Jewish Question, [w:] Focusing Galicia: Jews, Poles, s. 271-283; M. Janowski, Inteligencja wobec wyzwań nowoczesności. Dylematy ideowe polskiej demokracji liberalnej w Galicji w latach 1889-1914, Warszawa 1996, s. 109.

69 F. Braudel, Histoire et Sciences Sociales: La longue durée, Réseaux $\mathrm{nr} 27$ (1987), nr 5, s. 7-37.

70 Por. przypis 4.

71 R. Sandgruber, Österreichische Agrarstatistik 1750-1918 (= Wirtschafts- und Sozialstatistik Österreich-Ungarns, cz. 2), Wien 1978, s. 222.
} 
przemysłu włókienniczego w Karpatach, w nowoczesny przemysł fabryczny ${ }^{72}$. Słaba industrializacja i długotrwałe zapóźnienie w intensyfikacji rolnictwa doprowadziły w szczególności do silnego wzrostu sektora usług ${ }^{73}$. Handlowcy, kupcy i bankierzy byli niezbędnymi pośrednikami w regionie, a także $\mathrm{w}$ kontaktach poza granicami Galicji ${ }^{74}$. Oni też reprezentowali peryferyjną gospodarkę, która panowała w Galicji. $\mathrm{Z}$ jednej strony następowało tu zwiększenie importu towarów produkowanych w zachodnich habsburskich ośrodkach przemysłowych, ale także za granicą, w szczególności w Rzeszy Niemieckiej. Z drugiej strony Galicja coraz częściej eksportowała, jednak głównie surowce i produkty rolne, dlatego bilans handlowy na przełomie XIX i XX w. był konsekwentnie ujemny ${ }^{75}$. Galicja została zintegrowana w podział pracy imperium Habsburgów stosunkowo szybko i gwałtownie w końcu XVIII w. przez protekcjonistyczne środki wiedeńskiego dworu, ale również poprzez presję polityczną Prus ${ }^{76}$. Intensywność tej integracji wzrastała od lat czterdziestych XIX w. dzięki budowie linii kolejowych ${ }^{77}$. W latach trzydziestych XIX w. stopniowo wrócił

72 M. Kulczykowski, Andrychowski ośrodek płócienniczy w 18 i 19 wieku, Wrocław 1972; tenże, Chłopskie tkactwo bawetniane w ośrodku andrychowskim w 19 wieku, Wrocław 1976; tenże, „Deindustrializacja” $w$ procesach uprzemystowienia Galicji w XIX wieku. Problemy badawcze, [w:] Struktury, ruchy, ideologie XVII-XX wieku (Zeszyty Naukowe Uniwersytetu Jagiellońskiego DCCLIII), red. H. Kozłowska-Sabatowska, Kraków 1986, s. 75-87; tenże, Protoindustrializacja i deindustrializacja Galicji w latach 1772-1918. Problemy badawczy, Roczniki Dziejów Społecznych i Gospodarczych 50 (1989), s. 105-118.

73 L. Kool, Economic Development on the peripery. A case study of East Galicia, Ph.D. Temple University (Ann Arbour, Michigan) 1994, s. 160.

74 I. Schiper, Dzieje handlu żydowskiego na ziemiach polskich, Warszawa 1937.

75 Bilans handlowy dla lat 11784-1787, 1890-1892 i 1913 został obliczony według oficjalnych danych celnych i kolejowych: ÖStA (Österreichisches Staatsarchiv), Finanz- und Hofkammerarchiv (FHKA), Neue Hofkammer (NHK), Bankale, Bankaldirektionsakten, nr 2982: Merkantiltabellen M 3. Rocznik Statystyki Przemystu i Handlu Krajowego, Zeszyt XVII, Część II, Lwów 1895, s. 2-152; L.W. Biegeleisen, Stan ekonomiczny Matopolski na podstawie bilansu handlowego, Warszawa 1921, s. 273, 346-361; W stosunku do analizy ogólnej gospodarki Galicji w późnym XIX w.: P. Franaszek, Kluczowe zagadnienia dziejów gospodarczych Galicji na przetomie XIX i XX wieku, [w:] Galicja. Studia z dziejów spoteczno-gospodarczych, red. M. Bączkowski i T. Kargol, Kraków 2017, s. 67-82.

76 H. Grossmann, Österreichs Handelspolitik mit Bezug auf Galizien in der Reformperiode 1772-1790 (Studien zur Sozial-, Wirtschafts- und Verwaltungsgeschichte, t. X, red. K. Grünberg), Wien 1914. M. Drozdowski, Traktaty handlowe po pierwszym rozbiorze Polski a problem jedności gospodarczej ziem polskich, Roczniki Historyczne 37 (1971), s. 85-110.

77 K. Bachinger, Das Verkehrswesen, [w:] Die Habsburgermonarchie 1848-1918, t. I: Die wirtschaftliche Entwicklung, s. 278 n. 
wolny handel, co otworzyło Galicji aż do roku 1870 ponownie dostęp do tradycyjnych dla tego obszaru rynków zbytu (tj. do ziem polskich należących po rozbiorach do Imperium Rosyjskiego i Rzeszy Niemieckiej lub do handlu morskiego poprzez Gdańsk). Ponadto Galicja zyskała dostęp do nowych rynków ${ }^{78}$. Ale wraz z powrotem protekcjonizmu po okresie 1878-1882 kontakty te ponownie zostały utrudnio$\mathrm{ne}^{79}$. Chociaż nowa odsłona interwencjonizmu państwowego nie była już tak bezwzględna, jak to było 100 lat wcześniej, regulacja polityki celnej wzmocniła i tak już dominującą integrację gospodarki galicyjskiej w wewnętrzny rynek Habsburgów ${ }^{80}$.

Na przełomie XIX i XX w. słychać było w Galicji głosy ubolewające nad brakiem granicy celnej z innymi ośrodkami przemysłowymi monarchii habsburskiej ${ }^{81}$. Jak widać obwiniano więc niesprawiedliwy podział ponadregionalnej pracy Austro-Węgier za brak uprzemysłowienia Galicji - jeśli pominąć produkcję ropy naftowej i niektóre inne gałęzie gospodarki. Natomiast wpływ inwestycji zewnętrznych płynących do Galicji pod koniec XIX w. był konsekwentnie dodatni, chociaż o zbyt ograniczonym wymiarze żeby stworzyć konwergencję gospodarczą z innymi regionami habsburskimi (a oprócz tego stworzył on zależność wyższego rzędu) ${ }^{82}$. Odwrotnie, to właśnie ta słabość rozwojowa Galicji ufundowała dalsze wzajemne powiązania z innymi obszarami, a mianowicie emigrację, która osiągnęła znaczne rozmiary, szczególnie od

78 Centralnyj deržavnyj istoryčnyj archiv Ukraijiny, m. L'viv (CDIAL), fond (f.) 146, opys (op.) 80 sprava (spr) 252, nr 4460, Fol. 3-4 ; nr 8642, Fol. 14; f. 146, op. 80, spr. 254, Fol. 203-206; A. Beer, Die österreichische Handelspolitik im 19. Jahrhundert, Wien 1891 (nowe wydanie Wien 1972), s. 14 n; F. Tremel, Der Binnenhandel und seine Organisation. Der Fremdenverkehr, [w: Die Habsburgermonarchie 1848-1918, t. I: Die wirtschaftliche Entwicklung, s. 385; T. Huertas, Economic Growth and Economic Policy in a Multi-National Setting: The Habsburg Monarchy, New York 1977, s. 26-29.

79 H. Matis, Österreichs Wirtschaft 1848-1913. Konjunkturelle Dynamik und gesellschaftlicher Wandel im Zeitalter Franz Joseph I., Berlin 1972, s. 373-376; A. Beer, Handelspolitik im 19. Jahrhundert, s. 469 n, 479-482, 487-491.

80 K. Kaps, Galizisches Elend revisited. Wirtschaftsentwicklung und überregionale Arbeitsteilung in einer Grenzregion der Habsburgermonarchie (1772-1914), Zeitschrift für Weltgeschichte 14/2 (2013), s. 65 n.

81 J. Tuleja, O statystyce handlowej i przemysłowej Galicji, Kraków 1901, s. 2 n.; S. Anczyc, O przemyśle tkackim w Galicyi, Kraków 1903, s. 29 n.; K. Paygert, Podstawy do określenia zadań Galicyi na polu polityki handlowej, Kraków 1903, s. 352; Z. Gargas, W sprawie statystyki handlu zewnętrznego Galicyi, Lwów 1907, s. 3, 14.

82 H. Feldstein, Vermögens - und Zahlungsbilanz Galiziens, Lemberg-Leipzig-Wien 1917, s. 61-63, 86. Я.С. Хонігсман, Проникнення іноземного капіталу в економіку Західної України в епоху імперіалізму (до 1918 р.), Аьвів 1971. 
lat osiemdziesiątych XIX w. Przyczyną migracji był początek zmian strukturalnych w Galicji, co związane było ze wzrostem wydajności rolnictwa, a zwłaszcza wypierania krajowego rzemiosła przez produkcję fabryczną z innych regionów. W ten sposób powiązanie ponadregionalne i konkurencja wzajemnie się reprodukowały ${ }^{83}$. Oczywiście istotną rolę odgrywała kwestia wewnętrznej konstytucji regionu. Tak więc brak przedsiębiorczości, słabość klasy średniej i niechęć szlachty do wypełnienia roli przedsiębiorców w nowoczesnym tego słowa znaczeniu, były ważnymi elementami w tłumieniu czy też peryferyzacji Galicji w ponadregionalnym podziale pracy $^{84}$. Długotrwale niepewna sytuacja społeczna i częściowo trudna prawna sytuacja ludności żydowskiej w Galicji, przyczyniały się do słabości przedsiębiorczości. Liczne przykłady od późnego XVIII w. potwierdzą jak dyskryminacja ludności żydowskiej, która tylko częściowo została ułagodzona poprzez dekrety tolerancyjne wydane między 1781 i 1789 r., hamowała rozkwit przedsiębiorczości w Galicji ${ }^{85}$. Tymczasem wyższa klasa ludności żydowskiej posiadała znaczny potencjał przedsiębiorczy i wykazywała się różnorodną aktywnością podejmując rozmaite role w gospodarce - od dzierżawców po kupców do przemysłowców i bankierów ${ }^{86}$. Ściślej mówiąc, to właśnie wzajemna zależność niekorzystnej konkurencji ponadregionalnej i brak przedsiębiorczej elity doprowadziły do braku rozwoju Galicji.

Tak więc chociaż zintegrowanie Galicji w ponadregionalny podział pracy dało dość dwuznaczne wyniki dla rozwoju gospodarczego, to to samo można powiedzieć

83 A. Pilch, Migrations of the Galician Populace at the turn of the Nineteenth and Twentieth Centuries, [w:] Employment-seeking Emigrations of the Poles World-wide XIX and XX c. (Zeszyty naukowe Uniwersytetu Jagiellońskiego CCCCXVII, Prace Polonijne, Zeszyt 1), red. C. Bobińska, A. Pilch, Kraków 1975, s. 77-101; K. Hödl, Galician Jewish Migration to Vienna, [w:] Focusing Galicia: Jews, Poles, s. 147-163; E. Janik-Freis, Grenzregime am Dreikaiserreichseck: Galizische Auswanderung in die Amerikas, 1870-1914, [w:] Galizien in Bewegung. Wahrnehmungen - Begegnungen - Verflechtungen, red. M. Baran-Szołtys, O. Dvoretska, N. Gude, E. Janik-Freis, Göttingen 2018, s. 171-185.

84 F. Baltzarek, Zentralistische und föderalistische Aspekte der Wirtschaftspolitik am Beispiel Galiziens, [w:] Ausgebeutet oder alimentiert? Regionale Wirtschaftspolitik und nationale Minderheiten in Ostmitteleuropa (1867-1939) (Frankfurter Studien zur Wirtschafts- und Sozialgeschichte Ostmitteleuropas, tom 13), red. U. Müller, Berlin 2006, s. 63; K. Ślusarek, Sytuacja szlachty.

85 W. Häusler, Das galizische Judentum in der Habsburgermonarchie im Lichte der zeitgenössischen Publizistik und Reiseliteratur von 1772-1848, Wien 1979; ÖStA, FHKA, NHK, Kommerz, U Akten, nr 1564, 3 ex Januario 1794, Fol. 411-412. CDIAL, f. 146, op. 7, spr. 1887, 18857/1423. 86 T. Gąsowski, From Austeria to the Manor: Jewish Landowners in Autonomous Galicia, [w:] Focusing Galicia: Jews, Poles, s. 120-136. Andlauer, Bevölkerung, s. 165-193. 
o polityce imperialnej. Te dwie sfery zależały wzajemnie od siebie. Zawieranie kontraktów handlowych, ustanowienie ceł i zakazów eksportu i importu niektórych produktów wpływało bezpośrednio na wzajemny dostęp do rynków. Tak więc naprzemienna konkurencja zagraniczna na rynku regionalnym mogła być zmniejszona lub rozszerzona i vice versa, możliwości eksportowe dla produktów galicyjskich eksportowanych za granice państwowe mogły być promowane lub utrudniane.

Jeśli spojrzymy na politykę imperialną jako taką, musimy rozróżnić pomiędzy działaniami i ich wpływem z jednej strony a ich motywacją i inicjowaniem z drugiej strony. Na przykład promowanie handlu galicyjskiego było zadeklarowanym celem władz w polityce handlowej i celnej od początku panowania habsburskiego. Początkowo Wiedeń próbował zdefiniować specjalny status celny dla nowo zajętej prowincji. Ta regulacja miała zarówno utrzymać rolę Galicji w handlu tranzytowym i w eksporcie, przede wszystkim zbóż i płótna przez Gdańsk, a także powinna stopniowo poprawić dostęp producentów habsburskich, zwłaszcza z Czech i prowincji austriackich, do rynku galicyjskiego. W 1784 r. kiedy było już jasne, że nie da się tego celu zrealizować, szczególnie z powodu ceł, które Prusy nałożyły na transport Wisłą do Gdańska, Izba Dworska zarządziła włączenie Galicji do strefy celnej utworzonej w 1775 r. między krajami czeskimi i austriackimi ${ }^{87}$.

Galicja od tego czasu stanowiła część systemu handlu zagranicznego monarchii habsburskiej. Przepisy protekcjonistyczne z 1784 i 1788 r. spowodowały rozkład dotychczasowych międzynarodowych stosunków handlowych Galicji. W ten sposób zahamowano kontakty handlowe, które powstały na przestrzeni wieków, zwłaszcza między Galicją a innymi terytoriami byłej Rzeczpospolitej: Gdańskiem (i przez to pośrednio z Hiszpanią, Holandią i Wielką Brytanią oraz ich zamorskimi koloniami) i Imperium Ottomańskim. Jednocześnie wzrosła wymiana towarów z krajami czeskimi, austriackimi i węgierskimi, ale Galicja mogła tam sprzedawać tylko część swoich tradycyjnych towarów eksportowych. Przykładowo zboża niemalże nie były dostarczane na zachód i południe Monarchii ${ }^{88}$. Ze względu na niekorzystną sytuację geograficzną

87 H. Grossmann, Handelspolitik, s. 42, 44 n, 72 n, 221 n, 224, 252, 254, 374 n. S. Grodziski, Historia, s. 7; A. Komlosy, Grenze, s. 136.

88 A. Beer, Handelspolitik unter Maria Theresia, s. 116-119; M. Sauer, Aspekte der Handelspolitik des Aufgeklärten Absolutismus, [w:] Von der Glückseligkeit des Staates. Staat, Wirtschaft und Gesellschaft in Österreich im Zeitalter des Aufgeklärten Absolutismus, red. H. Matis, Berlin 1981, s. 241 n; H. Grossmann, Die amtliche Statistik des galizischen Außenhandels 1772-1792, Statistische Monatsschrift (1913), s. 222-233; ÖStA, FHKA, SUS, Varia 16 (nr 5 ). H. Grossmann, Handelspolitik, s. 123. 
dla transportu (np. brak spławnych rzek) występował wyraźny brak równowagi w stosunkach handlowych między Galicją i regionami habsburskimi. Mimo że warunki komunikacyjne zostały później znacznie polepszone przez budowę połączeń kolejowych, wspominana już kumulacja niekorzystnych procesów rozwojowych doprowadziła do pogorszenia niezbalansowanej struktury handlu zewnętrznego. Wynikiem tego był wysoki deficyt handlowy, zwłaszcza na wewnętrznym rynku habsburskim i w mniejszym stopniu z zagranicą ${ }^{89}$.

Polityka handlowa i celna państwa nie miała wyłącznie negatywnych aspektów dla Galicji. Wolny handel, a raczej liberalizacja międzynarodowego handlu towarami po latach trzydziestych XIX w., a zwłaszcza w latach pięćdziesiątych i sześćdziesiątych tego stulecia, poprawiła dostęp Galicji do tradycyjnych rynków na północy, zachodzie i wschodzie. Jednak tamtejsze warunki mocno zmieniły się przez prawie 100 lat nieobecności galicyjskich towarów, tak że trudno było rozwijać handel bazując na starych wzorcach wymiany. Faza odnowionego protekcjonizmu nie miała już tak potężnego wpływu na Galicję jak pod koniec XVIII w. Jednak nieuchronnie pogorszyła dostęp do rynku międzynarodowego dla galicyjskich produktów rolnych i surowców, w szczególności eksportowanych do Rzeszy Niemieckiej. Ta bariera jednak została tymczasowo złagodzona przez umowy dwustronne, unię celną Capriviego z lat 1891 i 1903 r. oraz inne umowy handlowe. Również liczne specjalne porozumienia negocjowane na poziomie bilateralnym pomogły podtrzymywać stosunki handlowe. Jednak protekcjonizm nie nosił wyłącznie negatywnych znamion dla galicyjskiej gospodarki, gdyż uchronił przed konkurencją międzynarodową różne sektory i gałęzi produkcji w rolnictwie i w przemyśle ${ }^{90}$. Można nawet dodać, że protekcjonizm lat 1784 i 1788 mógł stanowić potencjalną szansę dla Galicji. Właśnie zaniechanie lukratywnego eksportu surowców i produktów rolnych mogło być silnym bodźcem do wzrostu produkcji rzemieślniczej i proto-przemysłowej. To jednak nie powiodło się częściowo z braku zaangażowania szlacheckich elit, ale także częściowo ze względu na silną konkurencję ze strony tych regionów habsburskich, które już znalazły się w fazie proto-uprzemy-

89 Deficyt handlowy wzrósł od 2,2 i 2,1 miliona koron w latach 1779 i 1783 do 64,1 miliona koron (średnia z lat 1890-1892), zmniejszając się do 24,9 miliona koron w 1913 r., chociaż ta ostatnia statystyka obejmowała tylko część terytorium galicyjskiego. Zob. dane handlowe według oficjalnych statystykach dla lat 1779, 1783, 1890-1992 i 1913: H. Grossmann, Statistik; ÖStA, Haus-, Hof- und Staatsarchiv (HHStA), Kabinettsarchiv (KA), Nachlass Zinzendorf, Handschriften t. 118, s. 200 n. Rocznik Statystyki, s. 2-152. L. W. Biegeleisen, Stan ekonomiczny, s. 273 n, 346-361.

90 H. Matis, Österreichs Wirtschaft, s. 377-379; D. Turnock, The Economy of East Central Europe, 1815-1989. Stages of Transformation in a peripheral region, London-New York 2006, s. 38 n; T. Kargol, Izba, s. 147, 154, 163 n. 
słowienia i w latach tych przechodzily okres prawdziwego rozkwitu. Szereg nieudanych inicjatyw w postaci zakładania manufaktur przez galicyjskich magnatów w ich dobrach, jak i przez rzemieślników miejskich, potwierdzą strukturalne trudności, na które natrafiały próby zmiany peryferyjnego statusu galicyjskiej gospodarki w kontekście ponadregionalnego podziału pracy w monarchii habsburskiej ${ }^{91}$. Ta proto-przemysłowa koniunktura $\mathrm{w}$ regionach austriackich i czeskich była także promowana poprzez wspierany politycznie przez centrum dostęp do rynku zamówień i sprzedaży w Galicji1 ${ }^{2}$. Wywody te pokazują, że konkurencja na habsburskim jednolitym rynku wewnętrznym, poza istotnymi regulacjami politycznymi, była również ważnym elementem, często hamującym rozwój Galicji. Fakt ten choć na pierwszy rzut oka apolityczny, z perspektywy uwzględniającej przyłączenie Galicji jako zjawisko polityczne, był jednakże konsekwencją geopolitycznej ekspansji monarchii habsburskiej.

Państwo habsburskie interweniowało dodatkowo w regulacje dotyczące konkurencji międzyregionalnej, choć bardziej delikatnie. Tak więc niektóre petycje o kredyty państwowe lub dotacje dla działających w Galicji przedsiębiorców, zwłaszcza w sektorze tekstylnym, były w latach osiemdziesiątych XVIII w. odrzucane z argumentacją, że podobne placówki istniały już w krajach czeskich i austriackich ${ }^{93}$. Czasami wyraźnie stwierdzano, np. w pismach samego cesarza Józefa II-go, że konsumenci z Galicji powinni być zaopatrywani przez fabryki z regionów zachodnich, np. w tekstylia lniane ${ }^{94}$. To pokazuje, jak ponadregionalny podział pracy był kształtowany przez instytucje państwowe w granicach cesarstwa. Otóż interesy niektórych przestrzeni, jak tych już wcześniej wspomnianych proto-uprzemysłowianych centrów, były promowane ze szkodą dla innych regionów. Jednak w tym przypadku nie należy zakładać, że istnieje bezpośredni związek między misją cywilizacyjną lub stereotypowo-pejoratywnym postrzeganiem Galicji przez większość urzędników $\mathrm{z}$ jednej strony a dyskryminacją instytucjonalną z drugiej strony. Mimo że egzo-

91 E.K. Bacon, Austrian economic Policy in Galicia, 1772-1790, Diss. Chicago 1975, s. 68, 74, 106, 108, 114-120, 133-137, 146 n; ÖStA, HHStA, KA, Nachlass Baldacci, Karton 5 (5. Przemý́l); Karton 6 (7. Żółkiew, IV. Abtheilung: Commercial-Gegenstände). ÖStA, FHKA, NHK, Kommerz, U Akten, nr 1572, 10 ex Aprili 1810, Fol. 315-321; tamże, nr 1573, 30 ex Aprili 1811, Fol. 709-716. 92 H. Grossmann, Handelspolitik, s. 50-52, 62, 71.

93 ÖStA, FHKA, NHK, Kommerz, U Akten, nr 1563, 3 ex Februario 1793, Fol. 82-86; Tamże, nr 1558, 2 ex Julio 1782, Fol. 534-545; 1 ex Januario 1783, Fol. 570-579; 4 ex Majo 1784, Fol. 783, 795-799; Tamże, nr 1559, 3 ex Martio 1783, Fol. 617-622; Tamże, nr 1561, 12 ex Julio 1787, Fol. 340-356.

94 ÖStA, FHKA, NHK, Kommerz, U Akten, nr 1559, 1 ex Februario 1785, Fol. 982-987; tamże, 2 ex Martio 1785, Fol. 997-1003. 
tyczno-pejoratywne postrzeganie Galicji grało pewną rolę, to kluczowe przyczyny dla takiego modusu postępowania były inne. Raczej grały tu rolę ogólne względy polityczne i gospodarcze: $\mathrm{z}$ jednej strony biurokracja chciała chronić oraz promować te firmy, które z dużym nakładem sił zostały stworzone w Czechach i w krajach austriackich i po dlugim czasie odnosily w końcu sukces. Z drugiej strony, niepewny status Galicji w tym czasie przeciwdziałał otrzymywaniu przez jej przedsiębiorców zbyt hojnej pomocy pieniężnej od rządu. Potwierdzają to liczne plany wymiany Galicji na Śląsk, tzw. Prowincji Iliryjskie, Mołdawii i Wołoszczyzny aż do 1811 r. ${ }^{95} \mathrm{Jed}-$ nak mimo to także do Galicji płynęły fundusze rządowe, między innymi na wsparcie przedsiębiorstw rzemieślniczych. Ogólny poziom tych funduszów był jednak niski, a wsparcie było ograniczone do tych branż i przedsiębiorstw, które nie konkurowały z innymi regionami monarchii i ich przedsiębiorstwami. W każdym razie okres, podczas którego rząd dofinansował takie inicjatywy był dość krótki, kończąc się na początku lat dziewięćdziesiątych XVIII w. ze względu na brak środków finansowych, który objawił się w czasie wojen rewolucyjnych i napoleońskich ${ }^{96}$.

\section{Finansować imperium lub wspierać regionalny rozwój gospo- darczy? Podatki a inwestycje państwowe}

Inną kluczową kwestią w polityce gospodarczej państwa były podatki, a szerzej mówiąc dochody i wydatki rządowe w każdym z regionów. Nie chodzi tylko o kwotę fiskalną, ale o przychód netto, jaki otrzymywało państwo od każdej prowincji. Ta kwota netto nie zawierała pieniędzy, które państwo wydawało, np. na infrastrukturę lub edukację w tym regionie ${ }^{97}$. Oczywiście, badanie dystrybucji według prowincji lub krajów koronnych jest trudne, nie tylko ze względu na brak szczegółowych danych statystycznych ${ }^{98}$.

Przede wszystkim jest to związane z kwestią definicji, co traktowano jako wydatek na rzecz regionu, a co na rzecz całego imperium ${ }^{99}$, np. czy inwestycje minister-

\footnotetext{
95 H.-C. Maner, Kompensationsobjekt, s.106, 108; tenże, Galizien, s. 59 n.

96 E.K. Bacon, Austrian economic policy, s. 100, 112, 116 n, 119 n, 138 n, 144 n, 173.

97 K. Kaps, Ungleiche Entwicklung, s. 184 n.

98 M. Pammer, Public Finance in Austria-Hungary, 1820-1913, [w:] Paying for the Liberal state. The Rise of Public Finance in Nineteenth Century Europe, red. J.L. Cardoso, P. Lains, Cambridge 2010, s. 133, 139; J. Wysocki, Die österreichische Finanzpolitik, [w:] Die Habsburgermonarchie 1848-1918, t. I: Die wirtschaftliche Entwicklung, s. 79-81.

99 H. Feldstein, Vermögens- und Zahlungsbilanz, s. 45, 52-57, 86; S. Głąbiński, Samodzielność finansowa Galicji, Lwów 1906, s. 27-36, 61-63.
} 
stwa wojny w twierdze w Krakowie i w Przemyślu w drugiej połowie XIX w. należy uznać za wydatki, które w pierwszym rzędzie służyły imperium i utrzymaniu jego pozycji geopolitycznej, przekształcając Galicję w wielki mur ochronny imperium lub nawet teatr wojenny, czy też służyły interesom Galicji poprzez wzmocnienie bezpieczeństwa granic i obronę obszaru przed ewentualnymi atakami rosyjskiego wojska? Tutaj okoliczność, że te inwestycje miały pozytywne efekty dla gospodarki lokalnej (np. żołnierze tam stacjonujący zwiększyli pobyt na produkty lokalnych firm z okolic), była drugorzędną wobec faktu, że kluczowe części wyposażenia jak np. mundury, produkowano w innych regionach ${ }^{100}$.

Można również postawić pytanie, czy z linii kolejowych skorzystali galicyjscy producenci wyrobów rolnych i surowców, czy raczej przemysł czeski i austriacki lub ponownie, nawet wojsko, które mogło szybko przemieszczać swoje oddziały z jednego miejsca w drugie? ${ }^{101}$ Często inwestycje państwa służyły powszechnym, transgranicznym interesom. To odzwierciedla splecione procesy integracji całego imperium. Za tym stoi pytanie o legitymację władzy państwowej, która zarządzała tymi wydatkami. Jak to stwierdził Pieter Judson, była to właśnie polityka modernizacji, która dała imperium Austro-Węgier w swojej późnej fazie legitymację polityczną. To też jej brak spowodował upadek legitymacji Habsburgów właśnie podczas pierwszej wojny światowej ${ }^{102}$.

Na podstawie tych rozważań można stwierdzić, że Galicja nie była fiskalnie obciążona więcej niż inne kraje koronne zarówno w stosunku do ludności lub do powierzchni jak również do poziomu dobrobytu. Powtarzające się rozporządzenia,

100 M. Zgórniak, Galizien in den Kriegsplänen, s. 297, 300, 307; M. Baczkowski, Pod czarnozóttymi sztandarami. Galicja i jej mieszkańcy wobec austrowęgierskich struktur militarnych 1868-1914, Kraków 2003; Tenże, Inwestycje militarne w Galicji przed I wojna światowa, [w: ] Twierdza Przemyśl w Galicji, red. J. Polaczek, Przemyśl 2003, s. 17-27; Tenże, Galicja a wojsko austriackie 1772-1867, Kraków 2017; W. Wierzbieniec, Przemiany w społeczności żydowskiej Przemyśla w okresie autonomii Galicji. Próba oceny, Studia Judaica 1/2 (1998), s. 203. H.-C. Maner, Galizien, 187 n; F. Rochow, Die räumliche Erscheinungsform des Neoabsolutismus - Militärarchitektur in Lemberg und Wien in den 1850er Jahren, [w:] Zeitschrift für Ostmitteleuropa-Forschung 68/2 (2019), s.157-188.

101 Bericht der von dem Landtage zur Ausarbeitung des Projectes einer Galizischen Eisenbahn bestellten Commission, welcher von derselben den versammelten Ständen im Monate September 1842 erstattet wurde, Lemberg 1842, s. 1 n, 4-6, 10, 12; K. Bachinger, Verkehrswesen, s. 289; H.-C. Maner, Galizien, s. 260 n; T. Kargol, Izba, s. 185; M. Zgórniak, Galizien in den Kriegsplänen, s. 297, 300; ÖStA, FHKA, Finanzministerium - Präsidium, Hauptreihe (1814-1918), Akten, 2.498, 2258/1867, nr 3619. Praca, I /9 (10 VII 1863), s. 67.

102 P. Judson, Habsburg Empire, s. 333-441. 
które już pod koniec XVIII i na początku XIX w. ustalały niższe stawki podatkowe w Galicji niż w innych prowincjach, udowadniają uwzględnienie przez władze w Wiedniu niepewnych warunków życia ludności Galicji. Jednocześnie wydatki rządowe w Galicji pozostawały stosunkowo stabilne w stosunku do przychodów z tej prowincji w całym okresie ${ }^{103}$. Jednak ich cel zmienił się, bo początkowo wydatki przeznaczano głównie na ustanowienie i funkcjonowanie systemu administracyjnego w Galicji, a po 1867 r. coraz częściej na inwestycje w infrastrukturę, opiekę zdrowotną i edukację ${ }^{104}$. Wtedy zarówno administracja kraju koronnego i samorządy, które były wyposażone w znaczące prawa samorządowe, stały się dodatkowymi dostawcami usług publicznych ${ }^{105}$. Również siła przetargowa elity polsko-galicyjskiej, wzmocniona po 1867 r., w szczególności poprzez udział Koła Polskiego w austriackiej Radzie Państwa, wpłynęła na wzrost inwestycji państwowych, ale i też na przekazywanie części dochodów podatkowych do budżetu galicyjskiego, jak i na spłacanie długów krajowych ze środków ogólnopaństwowych ${ }^{106}$. Ta polityka jednak oznaczyła akceptację lub nawet bezpośredni udział w polityce fiskalnej ze strony Koła Polskiego w podwyższaniu istniejących podatków i wprowadzaniu nowych, jak to zrobił Julian Dunajewski jako minister finansów Przedlitawii i czego bronił również Stanisław Szczepanowski ${ }^{107}$.

103 K. Kaps, Ungleiche Entwicklung, s. 183-186; CDIAL, f. 146, op. 7, spr. 2239; Tamże, f. 146, op. 7, spr. 2240; H.-C. Maner, Galizien, s. 73.

104 ÖStA, FHKA, Oberster Rechnungshof, Zentralrechenabschlüsse 1781-1785, 1787-1788; ÖStA, HHStA, KA, Nachlass Zinzendorf, Handschriften 30b, s. 893-898; Tafeln für Statistik 1828-30, 1849-1857; Rocznik Statystyki Galicji II, s. 253-262; III, s. 282; IV, s. 348; Österreichisches Statistisches Handbuch für die im Reichsrate vertretenen Königreiche und Länder. Nebst einem Anhange für die gemeinsamen Angelegenheiten der österreichisch-ungarischen Monarchie, red. Statistische Zentralkommission, Jahrgänge 1-37, Wien 18931902. J. Wysocki, Infrastruktur.

105 K. Broński, Galicja w systemie podatkowym Austrii na przełomie XIX i XX w., Zeszyty Naukowe Akademii Ekonomicznej w Krakowie 655 (2004), s. 40; Tenże, Rozwój gospodarczy większych miast galicyjskich w okresie autonomii, Kraków 2003.

106 F. Baltzarek, Zentralistische und föderalistische Aspekte, s. 85. P. Franaszek, Die wirtschaftspolitische Gesetzgebung der Wiener Regierung und die ökonomische Entwicklung Galiziens im langen 19. Jahrhundert, [w: ] Ausgebeutet oder alimentiert? Regionale Wirtschaftspolitik und nationale Minderheiten in Ostmitteleuropa (1867-1939) (Frankfurter Studien zur Wirtschafts- und Sozialgeschichte Ostmitteleuropas, tom 13), red. U. Müller, Berlin 2006, s. 94, 98. 107 Tamże. E. März, Österreichs Industrie - und Bankenpolitik in der Zeit Franz Joseph I., Wien 1968, s. 256; C. Freiherr Marschall von Bieberstein, Freiheit in der Unfreiheit. Die nationale Autonomie der Polen in Galizien nach dem österreichisch-ungarischen Ausgleich von 
Nie oznacza to jednak, że polityka podatkowa nie prowadziła również do konfliktów między galicyjską peryferią a wiedeńskim centrum. Bynajmniej nie na tyle wyróżnia się tutaj szlachecki protest przeciwko reformie podatkowej józefińskiej z 1789 r., tak zwanej reformie urbarialnej. Warto podkreślić, że w owym czasie arystokracja prawie we wszystkich prowincjach monarchii stawiała opór przeciwko uldze dla wsi, kosztem właścicieli ziemskich i na korzyść państwa ${ }^{108}$. Raczej ważne są mniejsze, pozornie mniej znaczące tarcia, takie jak wzrost zreformowanego podatku konsumpcyjnego od wyrobów spirytusowych w 1835 r., który uderzył w dużym stopniu w przemysł galicyjski. Krytykę w mniejszym stopniu wywołała całkowita kwota fiskalna, lecz ważniejsza była jej struktura, gdyż poszczególne obiekty podatkowe (np. przemysł spirytusowy) nie miały takiego samego znaczenia we wszystkich regionach. Mogło to skutkować większym obciążeniem jednego kraju koronnego (np. Galicji) w porównaniu do drugiego ${ }^{109}$.

Wszystkie te ingerencje polityki ekonomicznej państwa w życie gospodarcze były ściśle powiązane z bieżącym paradygmatem polityki gospodarczej. Można zidentyfikować trzy główne fazy, a mianowicie kameralizm między końcem XVIII w. a 1830 r. Po tym okresie zastąpił go liberalizm, który nadał ton polityce gospodarczej aż do kryzysu 1873 r. W końcu rozpoczął się tak zwany „zorganizowany kapitalizm”, używając terminu Rudolfa Hilferdinga, który poprzez protekcjonizm, politykę infrastrukturalną i społeczną stworzył podwaliny dla nowoczesnego państwa podatkowego i interwencjonizmu ${ }^{110}$. Dwie $\mathrm{z}$ tych trzech faz charakteryzowały się zatem

1867. Ein konservativer Aufbruch im mitteleuropäischen Vergleich, Wiesbaden 1993, s. 344; S. Szczepanowski, Nędza Galicyi w cyfrach i program energicznego rozwoju gospodarstwa krajowego, Lwów 1888, s. 110 n, 118, 161, 209-211.

108 R. Rozdolski, Die große Agrar - und Steuerreform Josephs II. Ein Kapitel zur österreichischen Wirtschaftsgeschichte, Warszawa 1961, s. 121, 136-138, 140-142, 146-147, 158, 160-163 .

109 K. Broński, Galicja w systemie podatkowym, s. 40; M. Weiss, Das Verhältnis von direkten und indirekten Steuern hinsichtlich ihrer Erträge und ihrer Bedeutung für den Staatshaushalt unter besonderer Berücksichtigung der Belastung der Steuerträger (1781-1847), [w:] Beiträge zur Finanzgeschichte Österreichs (1740-1840), red. G. Otruba, M. Weiss, Linz 1986, s. 102-105; E. Saurer, Die Konsumbesteuerung Österreichs und Lombardo-Venetiens (1829-1859). Ein Vergleich, Mitteilungen des Instituts für Österreichische Geschichtsforschung 86 (1978), s. 392; R. Pieper, Financing an empire: the Austrian composite monarchy, 1650-1848, [w:] The Rise of Fiscal States. A Global History, 1500-1914, red. B. Yun-Casalilla, P.K. O’Brien, F. Comín Comín, Cambridge 2012, s. 188 n; J. Michalewicz, Przemyst gorzelniany Galicji doby autonomicznej. Między monopolem dworskim a monopolem państwowym, Kraków 1988.

110 A. Brusatti, Österreichische Wirtschaftspolitik vom Josephinismus bis zum Ständestaat, 
silną interwencją państwa w życie gospodarcze, co nieuchronnie miało wpływ na organizację ponadregionalnego podziału pracy.

Ogólnie rzecz biorąc, ocenę wpływu cesarskiej polityki gospodarczej na rozwój Galicji należy przeprowadzić według zróżnicowanych kryteriów, mocno zależnych od analizowanego okresu i przesunięcia paradygmatu polityki gospodarczej. Choć można znaleźć negatywne skutki z perspektywy rozwoju Galicji, zwłaszcza w odniesieniu do polityki handlowej i celnej, a częściowo także do polityki przemysłowej. Pozytywne wpływy można skonstatować przede wszystkim w polityce dotyczącej rozwoju infrastruktury i edukacji, a szczególnie w reformach rolnych w latach siedemdziesiątych i osiemdziesiątych XVIII w. Wydane wtedy prawa wzmocniły kontrolę ludności wiejskiej nad ich zasobami, ich prawa własności i społeczne jeszcze przed zniesieniem pańszczyzny przeprowadzonym w $1848 \mathrm{r}^{111}$

Ta uzasadniona pozytywna ocena pewnych elementów polityki imperialnej nie powinna jednak doprowadzić do konstatacji, według której była ona konsekwentna, wyłącznie pozytywna i, w rozumieniu linearnego modelu postępu, stanowiła niemal konieczny krok na drodze Galicji do nowoczesnej państwowości ${ }^{112}$. Taka interpretacja przeoczyłaby wewnętrzne interesy centrów imperialnych, które najwyraźniej widać w dyskursach cywilizacyjnych pochodzących z imperialnych elit. Jednak ludność galicyjska mogła przyjąć niektóre imperialne normy, praktyki i doświadczenia, aby realizować własne cele krajowe i narodowe. Naturalnie oczywiście ocena wpływu imperialnego doświadczenia na warstwy społeczne była bardzo różna. Przykładowo, reformy rolne uzyskały silne poparcie ze strony chłopów, podczas gdy wśród arystokracji wzmacniały obraz obcej dominacji ograniczającej jej tradycyjne prawa ${ }^{113}$. Ten

Wien 1965, s. 15, 19-21, 25 n, 28, 39-42, 45, 51, 53; E. Hanisch, Der lange Schatten des Staates. Österreichische Gesellschaftsgeschichte im 20. Jahrhundert, Wien 2005, s. 184 n; H. Matis, Österreichs Wirtschaft, s. 368 n.; tenże, Sozioökonomische Aspekte des Liberalismus in Österreich 1848-1918, [w:] Sozialgeschichte Heute, red. H.-U. Wehler, Göttingen 1974, s. 260.

111 R. Rozdolski, Stosunki poddańcze w dawnej Galicji, Warszawa 1962; Studia z dziejów wsi polskiej na przełomie XVIII i XIX wieku, red. K. Tomasz, B. Petryszak, K. Ślusarek, Kraków-Lwów 2015; Dwór, wieś i plebania w przestrzeni społecznej zachodniej Małopolski w latach 1772-1815, red. K. Tomasz, Ł. Jewuła, K. Ślusarek, Kraków 2015.

112 Zob. np. F. Baltzarek, Zentralistische und föderalistische Aspekte, s. 68; T. Kargol, Wirtschaftliche Beziehungen zwischen Galizien und den Ländern der österreichisch-ungarischen Monarchie in der ersten Hälfte des 19. Jahrhunderts, [w:] Die galizische Grenze 1772-1867: Kommunikation oder Isolation? (Europa Orientalis tom 4), red. C. Augustynowicz, A. Kappeler, Wien 2007, s. 48, 50.

113 R. Rozdolski, Stosunki poddańczy; tenże, Agrar-und Steuerreform. 
wewnętrzny antagonizm galicyjski miał ogromne znaczenie dla utrzymania rządów habsburskich, o czym świadczą chociażby wydarzenia Rabacji w 1846 r. ${ }^{114}$

\section{Konkluzje}

Na zakończenie trzeba raz jeszcze podnieść i wskazać na silne splątanie trzech przestrzenno-społecznych poziomów: imperium, regionu i narodu. Reprezentowały one trzy odrębne, ale ściśle ze sobą powiązane poziomy dominacji. Jednak ówczesne budowanie narodu w Galicji, zarówno wśród Żydów (szczególnie rozdrobnionych, z wieloma różnymi ścieżkami tożsamości), jak i Ukraińców i Polaków, z pewnością wyglądałoby inaczej bez imperialnego doświadczenia. Stwierdzenie Pietera Judsona, że naród i imperium są nawzajem nie tylko zależne, lecz powstają i rozwijają się w bliskim kontakcie ze sobą, ${ }^{115}$ oczywiście nabiera sensu tylko w połączeniu ze starszymi teoriami. Na pewno nie doszłoby do zastąpienia osobistych relacji panowania poprzez abstrakcyjne relacje społeczne, jak to podkreślał Ernest Gellner ${ }^{116}$. Dopiero modernizacja w szerokim znaczeniu tego słowa stanowi warunek konieczny do zastąpienia rozdrobnionych, lokalnych i społecznie zakotwiczonych tożsamości przez narody i ich równoprawnych obywateli. Podobnie, bez teorii Benedicta Andersona podkreślającej rolę komunikacji ${ }^{117}$, świadomość narodowa nigdy nie byłaby tak łatwo zrozumiana poprzez propagowanie i ujednolicenie poglądów. Połączenie tych elementów ilustruje proces budowania narodu, zwłaszcza w kontekście imperialnym. Galicja była wybitną konstrukcją imperialną, która bez względu na brak tradycji przed 1772 r. nie była zdolna do dalszej egzystencji administracyjnej po 1918 r. Również z powodu nacjonalizacji społeczeństwa, ten specyficzny region najszybciej stracił swoją legitymację, jeszcze zanim doszło do erozji cesarskiej władzy długo przed 1918 r. Dowodzą tego liczne transgraniczne kontakty i lojalności ${ }^{118}$.

114 S. Kieniewicz, The Emancipation of the Polish Peasantry, Chicago 1969, s. 118-120, 123 n.; P. Judson, Habsburg Empire, s. 110; Rok 1846 w Krakowie i Galicji. Odniesienie, interpretacje, pamięć, red. K.K. Daszyk, T. Kargol, T. Szubert, Kraków 2016.

115 P. Judson, Habsburg Empire, s. 1-15, 274, 333-384.

116 E. Gellner, Nations and nationalism, Ithaca 1987.

117 B.R. O'G. Anderson, Imagined communities. Reflections on the origin and spread of nationalism, London 1993.

118 B. Kuzmany, L.R. Cohen, P. Adelsgruber, Kleinstädte entlang der galizisch-wolhynisch/ podolischen Grenze. Ein Vergleich, Jahrbücher für die Geschichte Osteuropas 55 (2007), s. 210-241; C. Augustynowicz, Grenze(n) und Herrschaft(en) in der kleinpolnischen Stadt Sandomi- 
Uderzającą różnicę można zauważyć między Galicją a innymi austriackimi krajami koronnymi, które w pierwszej Republice austriackiej po 1918 r. były niemal identyczne z nowo utworzonymi krajami federalnymi. Poziom regionalny jest ważną jednostką przestrzenną w badaniu procesów społecznych, ponieważ precyzyjnie wyznacza przestrzeń gdzie imperium i narody krzyżują się i spotkają się wzajemnie.

Nadesłany: 30 VII 2018

Nadesłany po poprawkach recenzyjnych: 27 IX 2019

Zaakceptowany: 29 IX 2019

Dr. Klemens Kaps

Senior Lecturer

Institut für Neuere Geschichte und Zeitgeschichte

Johannes Kepler Universität, Linz

Altenberger Straße 69

Keplergebäude, K 270D

4040 Linz, Österreich

klemens.kaps@jku.at

\section{Economy, politics and identity: Galicia and the Habsburg Monarchy in the $19^{\text {th }}$ century in the light of the historiographical debate on empire, nation and region}

Recently, history as a discipline of science has experienced a spatial turn; global history has corroborated the focus on intertwined regions, states and empires in terms of economic, social and cultural interactions. By applying new approaches to empires, this article reconsiders the economic development of Habsburgs' Galicia between the annexation and separation of this region in the First Partition of the Polish-Lithuanian Commonwealth until the end of WWI and the fall of the Habsburg Empire. The major argument put forward in this article is that economic growth was heavily influenced by both the political institutions and the cultural identities in Galicia which transformed into national identities in the course of the eventful $19^{\text {th }}$ century. Three development phases have been identified, corresponding with different economic paradigms, namely cameralism, liberalism and organized capitalism. They have been superimposed onto the social structure, the changing institutional frame-

erz, 1772-1844, Wien 2015; A.V. Wendland, Die Russophilen in Galizien. Ukrainische Konservative zwischen Österreich und Rußland, 1848-1915, Wien 2001; A. Chwalba, Historia Polski. 
work of the Habsburg Empire ranging from efforts at centralization in the late $18^{\text {th }}$ century to democratization and federalization concessions in the 1860s, coupled with the formation of group identities in regions, cultures and nations. Trade and industry-related policies often hampered Galicia's economic growth giving preference to the economic core areas in Bohemia and Austria at the expense of the newly acquired province on the outskirts of the Empire. Many other areas acquired a much more ambivalent status. This holds true for the fiscal policy where the net tax in Galicia equalled the average tax, and for many public investments, in particular after 1867, improved infrastructure and education. On the other hand, the agrarian reforms improving the legal position of tenants against their lords is another example of the positive effects of the Habsburg rule on Galicia's economy. However, all of the measures differently affected the region's population according to the social position and economic and political interests. Oftentimes, it is impossible to clearly separate the benefits for the region and for the empire, e.g. when the construction of railways stimulated regional exports as well as imports, pushing the regional producers from the market. Another example are military investments which improved national security but were strictly related to the Empire's geopolitical position to which the region had to contribute by being a part of a pact (questionable from a national perspective) and the main theatre of war. The evolving national identities posed an increasing threat of adding an ethnic aspect to the economy. However, there were important factors, predominantly social ones, that kept in check the demarcation lines and contributed to maintaining a high level of intercultural cooperation. In fact, while Galicia's peripheral economic position in the Habsburg Empire strongly provoked inter-ethnic conflicts and struggle for limited resources, it was an imperial framework conducive for forging national identities. 